\title{
Articles
}

\section{Platonic Love in a Colorado Courtroom: Martha Nussbaum, John Finnis, and Plato's Laws in Evans v. Romer}

\author{
Randall Baldwin Clark*
}

\section{RELEVANT FOR FIFTEEN MINUTES - OR THIRTY CENTURIES?}

To the ridicule of the highbrow popular press ${ }^{1}$ and the surprise of classical scholars, ${ }^{2}$ Plato's Laws, ${ }^{3}$ a work which was mocked, even in

* University of Virginia School of Law, Class of 2002. Ph.D., University of Chicago, 1998.
Research Associate, Dartmouth College Department of Government, 1997-99. Author, THE
LAW MOST BEAUTIFUL AND BEST: MEDICAL ARGUMENT AND MAGICAL RHETORIC IN
PLATO'S LAWS (Rowman \& Littlefield - Lexington Books, forthcoming 2001). This article has
benefited from the comments of many friends, colleagues, and teachers. For their assistance, I
would like to thank Danielle Allen, Larry Arnhart, Richard O. Brooks, Robert A. Burt,
Allison D. Clark, Andrew P. Clark, Elizabeth A. Clark, Glenn W. Clark, Matthew Crawford,
Richard Dougherty, Martha A. Field, Shawntel R. Fugate, Martin P. Golding, L. Kent
Greenawalt, A.E. Dick Howard, Leon R. Kass, Matthew Kutcher, Melissa S. Lane, Mark J.
Lutz, Roger D. Masters, Lynn Mather, Angelia K. Means, Ted H. Miller, S. Sarah Monoson,
David Peritz, Richard A. Posner, Christopher Rohrbacher, Ariel C. Silver, Nathan Tarcov,
Bradley A. Thayer, Elizabeth E. Theran, Paul Ulrich, Eduardo A. Velasquez, Lloyd L.
Weinreb, Martin D. Yaffe, and the members of my edit team at the Yale Journal of Law \& the
Humanities. I only regret that I was unable to address all of their criticisms. Particularly
profound appreciation is owed to my friend and colleague, James B. Murphy, whose queries
helped me conceive this work and whose encouragement brought it to light: aneu gar philôn
oudeis heloit' an zenn. Financial support for my research was generously provided by the Joseph
B. Obering Foundation, the Andrew W. Mellon Foundation, the John M. Olin Foundation, the
Lynde and Harry Bradley Foundation, and the Dartmouth College Department of
Government.

1. See, e.g., Jeffrey Rosen, Sodom and Demurrer: Should the Courts Deliver Gay Civil Rights?, THE NEW REPUBliC, Nov. 1993, at 16.

2. See, e.g., John M. Rist, Plato and Professor Nussbaum on Acts 'Contrary to Nature', in 
antiquity, for its aesthetic frigidity, ${ }^{4}$ has enjoyed of late a remarkable fifteen minutes in the sun. In "expert witness" testimony and affidavits $^{5}$ submitted in October 1993 to a Colorado district court in Evans $v$. Romer ${ }^{6}$ and in subsequent clarificatory (and obfuscatory) articles, ${ }^{7}$ three prominent scholars, John Finnis, Martha Nussbaum, and Robert George, vituperatively contended over the potentially pejorative meaning of the word tolmêma at $636 \mathrm{c}$ of this lengthy Platonic dialogue. ${ }^{8}$ Finnis and George, for their part, argued that this term is inherently aspersive - "those first guilty of such enormities (tolmêma) were impelled by their slavery to pleasure"-and sought to show that this passage's characterization of homosexual sodomy as "contrary to nature" (para phusin) demonstrates Plato's antipathy toward homosexual conduct as well as his affirmation of the moral centrality of wedded heterosexual intercourse. Nussbaum, in rebuttal, claimed that this passage, when translated in a morally "neutral" manner-she prefers "those who first ventured to do this" - is generally supportive of her (and Plato's) view of homosex-

Studies in Plato and the Platonic Tradition: Essays Presented to John WhITTAKeR 65 (Mark Joyal ed., 1997); Mary R. Lefkowitz, Contemporary Culture, in TIMES LIT. SUPP., Mar. 17, 1995, at 23.

3. Plato, Laws (Thomas Pangle ed. \& trans., Univ. of Chicago Press 1988).

4. See ARISTOTLE, The Polmtics 1265a1-2 (Stephen Everson ed. \& Benjamin Jowett trans., Cambridge Univ. Press 1988); LUCIAN, ICAROMENIPPUS OR THE SKY MAN 24 (A.M. Harmon ed. \& trans., Loeb Classical Library 1915).

5. Addendum to Rebuttal Affidavit of John Finnis (Oct. 27, 1993) [hereinafter Finnis Addendum to Rebuttal Affidavit]; Rebuttal Affidavit of Robert George (Oct. 22, 1993); Rebuttal Affidavit of John Finnis (Oct. 21, 1993); Affidavit of Martha Nussbaum (Oct. 21, 1993) [hereinafter Nussbaum Affidavit]; Testimony of Robert George (Oct. 20, 1993) [hereinafter George Testimony]; Testimony of Martha Nussbaum (Oct. 15, 1993) [hereinafter Nussbaum Testimony]; Affidavit of John Finnis (Oct. 8, 1993) [hereinafter Finnis Affidavit]; Deposition of Robert George (Oct. 8, 1993); Expert Witness Summary for Professor Martha Nussbaum [hereinafter Nussbaum Surnmary]. The docket number for Evans $v$. Romer is 92 CV7223

6. Evans v. Romer, 63 Empl. Prac. Dec. (CCH) I 42,719 (Colo. D. Ct. 1993), aff d, 882 P.2d 1335 (Colo. 1994), aff', 517 U.S. 620 (1996).

7. For Finnis's contribution, see John Finnis, "Shameless Acts" in Colorado: Abuse of Scholarship in Constitutional Cases, ACAD. QUESTIONS, Fall 1994, at 10 [hereinafter Finnis, "Shameless Acts"]; John Finnis, Law, Morality, and "Sexual Orientation," 9 NoTRE DAME J.L. ETHICS \& PUB. POL'Y 11 (1995). (In a later essay, Finnis continued his discussion of some of the issues raised in the case. See John Finnis, The Good of Marriage and the Morality of Sexual Relations: Some Philosophical and Historical Observations, 42 AM. J. JURIS. 97 (1997).) Nussbaum responded with Platonic Love and Colorado Law: The Relevance of Ancient Greek Norms to Modern Sexual Controversies, 80 VA. L. REV. 1515 (1994) [hereinafter Platonic Love], an abridged version of which was later reprinted in SEX AND SOCIAL JUSTICE 299 (1999). George made his public contribution in "Shameless Acts" Revisited: Some Questions for Martha Nussbaum, ACAD. QUESTIONS, Winter 1995-96, at 24. Like Finnis, George has continued to address the broader normative issues raised by this debate. See Patrick Lee \& Robert P. George, What Sex Can Be: Self-Alienation, Illusion, or One-Flesh Union, 42 AM. J. JURIS. 135 (1997).

8. All citations of the Laws in this essay use the Stephanus pagination, a reference system common to almost every published version of this work. 
ual relations as benign, even salutary. ${ }^{9}$

The pretext for these philological exertions in a Denver district courtroom was not, we note with some regret, the judge's abiding interest in the tolmaô verb family, but rather an issue of somewhat greater legal import. Did Amendment 2 to the Colorado Constitution-which forbade any state agency from designating homosexual, lesbian, or bisexual "orientation, conduct, practices, or relationships" as the basis for protected legal status ${ }^{10}$ - constitute an impermissible establishment of religion on account of its allegedly irrational hostility toward homosexuals?

The history of the case is well known, but bears repetition." Shortly after Amendment 2 passed in a 1992 referendum with fiftythree percent of the vote, a group of plaintiffs obtained an injunction from District Court Judge H. Jeffrey Bayless. Ultimately upheld by the Colorado Supreme Court, the case was sent back to the same judge for trial. Among the various arguments presented by the plaintiffs in the pre-trial motions was the claim that, because "the 'moral judgment' expressed by Amendment 2 is nothing more than irrational hostility toward lesbians, gay men, and bisexuals, Amendment 2 does not serve any legitimate purpose."12 They argued, therefore, that this amendment constituted an impermissible establishment of religion: "Amendment 2 is based upon and embodies a particular religious view regarding gay, lesbian and bisexual orientation." ${ }^{\prime 13}$

Hoping to counter these arguments, Tim Tymkovich, the Solicitor General of Colorado, enlisted the services of John Finnis, Professor of Law and Legal Philosophy at Oxford and an author of treatises on natural law jurisprudence. In his affidavit, Finnis argued for the presence in the Western legal and philosophical tradition of a nonbiblical civic antipathy toward the practice of homosexual congress.

9. See, e.g., Nussbaum Affidavit, supra note 5, 9 17. In my efforts in this Article to make sense of the Laws and the various commentaries thereupon, I will make use of three termssodomy, homosexuality, and pederasty - to describe various manifestations of homoerotic behavior considered in the dialogue. I do so with some apprehension, for I recognize that these English words describe phenomena which are both distinct and overlapping, and map very poorly onto ancient conceptions. I have, therefore, gone to great pains to ensure that on each occasion in which I refer to one of these words, my usage most clearly and accurately represents the sense of the passage under consideration. On no occasion in this Article, however, do I intend to speak of either heterosexual pederasty or sodomitic relations between men and women.

10. Colo. Const. amend. II.

11. For an even-handed account of the trial and the events leading up to it, see Daniel Mendelsohn, The Stand: Expert Witnesses and Ancient Mysteries in a Colorado Courtroom, LINGUA FRANCA, Sept.-Oct. 1996, at 34.

12. Id. at 36.

13. Amended Complaint II 42 (Dec. 23, 1992). 
In these efforts to demonstrate a secular and rational condemnation of sodomy in this tradition, Finnis treated a broad range of thinkers, extending forward to Kant and Hume, but located its genesis in the Greek philosophers Socrates, Plato, and Aristotle. ${ }^{14}$

To rebut Finnis's arguments, the plaintiffs engaged Martha Nussbaum, then Professor of Classics and Philosophy at Brown, whose pre-trial summary statement claimed that "prior to the Christian tradition there is no evidence that natural-law theories regarded same-sex erotic attachments as immoral, 'unnatural,' or improper." 15 As she went on to argue in this document, any natural law theory-such as that advanced by John Finnis - that "condemns gay or lesbian sexual conduct and relationships as a violation of natural law or natural human good ... is inherently theological." ${ }^{\text {.16 }}$ To argue against her claim that Western moral objections to homosexual conduct have no extra-biblical and hence no rational basis, the defense subsequently called in Robert George, Professor of Politics at Princeton.

As a result of the sharp disagreement between the views expressed (and methods employed) in Nussbaum's and George's testimonies, all three parties saw fit to clarify and expand their arguments: Each of them submitted to the court at least another written explication of his or her own position along with a criticism of the other side. So sharp were their disagreements, however, that, even after Judge Bayless had handed down a verdict in the plaintiff's favor, the antagonists have continued-some to this day-to prosecute their arguments in scholarly fora. ${ }^{17}$

Even though these witnesses' various efforts to demonstrate, in this single modern case, the presence or absence in the Western tradition of a rational, non-religious civic antipathy toward homosexual congress revealed to the court and the academy a panoramic view of Western philosophy, a particularly privileged place in this debate was given to the Laws. As Finnis boldly declared: In this dialogue can be found several "unmistakably clear" attacks on the "unnatural" act of sodomitic congress. ${ }^{18}$ The same Plato, he wrote, who celebrated "romantic and spiritual" homosexual relations in the Symposium "also made very clear that all forms of sexual conduct outside heterosexual marriage are

14. See Finnis Affidavit, supra note 5, 11 29-53.

15. Nussbaum Summary, supra note 5, at 1.

16. Id. at 2.

17. See supra note 7 .

18. Finnis, Law, Morality, and "Sexual Orientation," supra note 7, at 23. 
shameful, wrongful and harmful."19 Nussbaum directed even more energy towards problematizing these passages to which Finnis refers. Her post-trial piece in the Virginia Law Review, "Platonic Love and Colorado Law," is remarkable for its careful scrutiny of these purportedly "unmistakably clear" attacks on homosexuality in the Laws. ${ }^{20}$

Although Plato's scholarly cheerleaders (like myself) are no doubt pleased that this obscure and underappreciated dialogue has had occasion to occupy center stage, if only briefly, in this momentous public debate, they do have some cause for discomfort with the treatment it has received from these "expert witnesses." Valuable and interesting questions were in fact raised by the testimony and subsequent debate: Is homosexual congress unnatural (and what does that imply)? How can we assess the moral character of sexual behavior? And, quite pressingly, what role should the state play in shaping our proclivities and restricting our (self-)injurious behavior? But the rich texture of Plato's consideration thereof was entirely overlooked as the various partisans sought to advance their respective political agenda by adducing and rebutting proof-text references to the Laws.

Much of this trivialization of the Laws-viz., the treatment of a philosophical text with the disrespectful exegesis traditionally accorded only to sacred writ-is due, no doubt, to the partisan character of legal discourse: Each sought to prove his or her point to an untutored judge and adduced plausible arguments and Platonic passages supportive thereof. Less understandable, however, is the persistence of this methodology in the post-trial publications proffered by each of the participants. Finnis and George, in each of their articles in Academic Questions, return to the question-vigorously contested in the trial itself-of the proper translation of tolmêma at $636 \mathrm{c}^{21}{ }^{21}$ But even as they argued that Finnis's reliance on R.G. Bury's translation ${ }^{22}$ of this word as "enormities" is not unreasonable, they largely left to the side their substantive claims concerning the moral centrality of wedded love in the Laws. Instead, they directed their energy toward castigating as perjury Nussbaum's representation to the court that the 1897 version of Liddell \& Scott's A Greek-English Lexicon-containing an entry for tolmêma more friendly to her cause than those set out in the more recent (1940 and

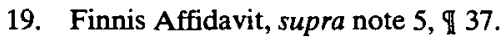

20. Nussbaum, Platonic Love, supra note 7.

21. See Finnis, "Shameless Acts," supra note 7, at 19-35; George, "Shameless Acts" Revisted, supra note 7, at 24-36.

22. Plato, LAWS (R.G. Bury ed. \& trans., Loeb Classical Library 1926). 
1968) editions of this classic work - was the "authoritative dictionary relied on by all scholars in this area." ${ }^{, 23}$

Nussbaum, for her part, confronts the substantive question-what does Plato say in the Laws about homosexual intercourse?-headon, but does so in an entirely unsatisfactory manner. While she brings tremendous philological acumen to bear on the several passages in which homosexual desire is treated, she does so in a misleading manner: Textual molehills are consistently surveyed as insurmountable mountains and clear condemnations are presented as rhetorical Gordian knots. Most distressing of all, in her eagerness to argue - to both the court and the academy - for the benign (if not wholly praiseworthy) character of homosexual congress, Nussbaum fails to situate the Laws' condemnations within the broader, and much more illuminating, context of this dialogue's overall treatment of sexual desire, its relationship to the family, and the state's interest in regulating both.

This is, I believe, a shame. For the Laws offers its readers a provocative presentation of the problematic character of both homosexual desire and the family, as well as a thoughtful consideration of the appropriate governmental role in the regulation of both-pressing issues still. Had these disputants-after the hour of the agon passed-favored us with a more leisurely, even scholarly, consideration of these questions, we might have learned something about Plato's views concerning the narcissistic character of (homo)erotic desire, the fragility of family life, and the city's interest in the gentle redirection of the former in order to sustain the latter. These are, no doubt, contentious claims, both in Plato's time and in our own. Many of those (myself included) who observed the progress of Romer as it passed through the courts likely harbor views quite different from the various arguments Plato's interlocutors present over the course of the Laws. None of us, however, regardless of personal opinions concerning these matters, were particularly well served when the import of this potentially eye-opening dialogue was obscured by the provocation of legal catfights and the stirring-up of philological duststorms. Plato records his teacher's claim to act as a gadfly, stinging his somnolent fellows to an awareness of their ignorance. Plato's mature consideration of these issues in the Laws could come as a pique to our own thoughtless prejudice, no matter where it might lie. None of this can occur, however, unless we allow him to engage us, not in contextually unencumbered sound-bites, but on his own discursive terms.

23. Nussbaum Affidavit, supra note 5, II 10. See Finnis, "Shameless Acts," supra note 7, at 19-35; George, "Shameless Acts" Revisted, supra note 7, at 24-36. 


\section{HOMOPHOBIA: PAUline OR PLATONIC?}

The primary interpretive issue raised in this debate is whether the various passages in Plato's Laws in which homosexual congress is discussed evince the presence of a pre-Christian, extra-biblical civic antipathy toward the practice. On the face of it, the answer is clearly positive: In two of the three passages where the practice is explicitly mentioned, the dialogue's protagonist, an unidentified traveler hailing from Athens, describes sodomy as unnatural $;^{24}$ in the third, he legally proscribes its practice. ${ }^{25}$

For John Finnis, this characterization constitutes a definitive case against sodomitic congress. So clear in fact do these passages in the Laws appear to Finnis that he is impelled to make quite bold claims about Plato's general views in this regard. In his affidavit to the court, Finnis exults in the similarity of these condemnations to later Christian teachings concerning sexual morality. After citing these passages $^{26}$ to argue that "the same Plato who in his Symposium wrote a famous celebration of romantic and spiritual man-boy erotic relationships also made very clear that all forms of sexual conduct outside heterosexual marriage are shameful, wrongful and harmful, ${ }^{27}$ he proceeds to note that distinguished Plato scholars have remarked, with much regret, on the similarity of these condemnations to the views of Pope John Paul II: "Some recent scholars (overlooking Christianity's Jewish roots and own indigenous resources) go so far as to attribute Christian sexual morality to the influence of Plato, so thorough is the convergence on matters of sexual conduct." ${ }^{28}$

His claims are even more aggressive in his two post-trial articles,

24. See PLATO, supra note 3 , at $636 \mathrm{~b}-\mathrm{c}, 836 \mathrm{c}$.

25. See id. at $838 \mathrm{e}$.

26. See Finnis Affidavit, supra note 5, II 37 ("I refer to PlATO, THE LAwS I, 636C, VIII, 836B-D, 837B-C, 838E, 840D-841E.").

27. Id.

28. Id. II 37. One of these scholars, A.W. Price, writes:

Thus Plato's evolving attitude towards sexuality soon takes on nuances beyond an undiscriminating philosophical distaste for physical indulgence. It is likely that in his eventual estimation and even imposition of parenthood he frees himself, without hypocrisy, from his own involuntary repugnance (which PHAEDRUS 250e3-5 fleetingly betray); if so, he has achieved the best of victories, that over oneself (LAWs 1.626e2-3). However, to the extent that Plato is linked to John Paul II by a chain of influence, his heroism has cost others dear. Most of us must wish that his sexual prohibitions had never escaped from utopia; and yet, however questionable his grounding of them may be, in detail or in general, its integrity and originality invite from us all a detached curiosity and respect.

A.W. Price, Love AND Friendship in Plato And ARistotle 234-35 (1989). For Finnis's detailed comments on Price's observation, see Law, Morality, and "Sexual Orientation," supra note 7, at 22, and "Shameless Acts," supra note 7, at 29. 
where he points out that the various scholarly authorities to whom Nussbaum appeals "all concur in using the terms 'unnatural' or 'contrary to nature' to translate para phusin as predicated on homosexual acts in Laws" and that "[a]ll judge that para phusin, as used by Plato in the Laws, must be understood as the core of a very firm and unqualified condemnation of homosexual conduct. ${ }^{, 29} \mathrm{He}$ continues:

Like even Halperin and Winkler..., Dover, Price, and... Vlastos all judge that to know or tell Plato's views on the morality, the immorality, of all such non-marital conduct as homosexual sex acts, one need go no further than these unmistakably clear passages in the Laws, texts with which every other text of Plato can readily be seen to be consistent. ${ }^{30}$

Most amazingly, by extrapolating from this negative argument (sodomy is unnatural and thus immoral), Finnis is able to find in the Laws a positive defense of the intrinsic goodness and desirability of marriage. "At the heart of the Platonic-Aristotelian and later ancient philosophical rejections of all homosexual conduct," Finnis declares in his affidavit, "are three fundamental theses." ${ }^{11}$ First: "The commitment of a man and women to each other in the sexual union of marriage is intrinsically good and reasonable, and is incompatible with sexual relations outside marriage." ${ }^{32}$ Second: "Homosexual acts are radically and peculiarly non-marital, and for that reason unnatural and unreasonable." Third: "Furthermore, according especially to Plato, homosexual acts have a special similarity to solitary masturbation, which is manifestly unworthy of the human being and immoral." ${ }^{33}$ As evidence for these claims, Finnis quotes and comments on two (previously cited) passages from the Laws. He first notes Plato's characterization at $636 \mathrm{c}$ of the pleasures of heterosexual intercourse as "due to nature" and the pleasures of homosexual intercourse as "contrary to nature." "[U]niting for procreation," Finnis explains, "in fact refers to marital intercourse." 34 This "is made clear," he suggests, "in a later passage in the same work, where Plato's mouthpiece sums up his intervening

29. Finnis, Law, Morality, and "Sexual Orientation," supra note 7, at 23. See also Finnis, "Shameless Acts," supra note 7, at 29.

30. Finnis, Law, Morality, and "Sexual Orientation," supra note 7, at 23, and "Shameless Acts," supra note 7, at 29.

31. Finnis Affidavit, supra note 5, Il 41. See also Finnis, Law, Morality, and "Sexual Orientation," supra note 7 , at 25 .

32. Finnis Affidavit, supra note 5, II 41.

33. Id.

34. Id. I 42. 
commendation of marital intercourse and condemnation of extramarital sexual activity by proposing two quasi-alternative laws to govern sexual conduct in the as-near-as-can-be-ideal state. ${ }^{\prime 35}$ After quoting the final (and confusing) adultery laws at $841 \mathrm{c}-\mathrm{e}$, Finnis concludes: "Plato's last word on sex thus makes explicit the rationale for what Socrates (while homoerotically playing with fire) implicitly taught by his actual conduct: sexual conduct is consistent with human integrity only in marriage." 36

In response to John Finnis's assertion of the Laws' antipathy toward homosexuality and praise of conjugal fidelity, Martha Nussbaum assiduously seeks to demonstrate this dialogue's profound neutrality toward both. Plato's animus, she argues, is directed toward neither the natural nor the unnatural character of any particular form of sexual intercourse, but, rather, the immoderation with which the sexual actor proceeds. The sexual crime to be found in the Laws, she asserts, is incontinence, not sodomy.

Of Nussbaum's various concerns, the first of these-to demonstrate that John Finnis and Robert George "are simply wrong in claiming that classical philosophy, particularly the works of Plato and Aristotle, condemn gay and lesbian relationships as immoral" ${ }^{37}$-is most directly addressed in the documents emanating from the trial itself. Her basic claim, advanced in her oral testimony to the court on October 15, was that Finnis misinterpreted 636c on account of his reliance on R.G. Bury's prudish and outdated (1926) translation of the Laws. ${ }^{38}$ As Nussbaum asserts: Because "there was a great deal of shame and embarrassment about homosexuality in the British and American cultures ... morally neutral phrases such as 'those who first venture to do this,' namely, have same-sex relations, are translated 'those who were first guilty of such abominations.",39 After Robert George pointed out in his testimony that all other readily accessible major translations of the work, both dated and recent, translate the word in question with similarly negative renditions ${ }^{40}$ Nussbaum invoked the definition supplied by "Liddle [sic], Scott, __ [sic] Lexicon of the Ancient Greek Language [sic], the authoritative dictionary relied on by all scholars in the area," to argue for a more neutral translation of tolmêma: "an adventure,

35. Id.

36. Id.

37. Nussbaum Affidavit, supra note 5, $\llbracket 2$.

38. See Nussbaum Testimony, supra note 5, at 11.

39. Id.

40. See George Testimony, supra note 5, at 1320 ("When I checked various translations, I found that it was sometimes translated as shameful acts, sometimes translated as crimes, sometimes as offences, sometimes as outrages."). 
enterprise, deed of daring." ${ }^{41}$ As she later elaborates: "I have chosen the more neutral 'venture,' since it seems to me that in the context Plato is being neutral, and since it seems best not to read in a positive connotation if one is not absolutely certain.,"42

Nussbaum then proceeds to address one of Finnis's other major assertions: that sodomy is unnatural and hence shameful. To accomplish this, she again suggests that Finnis makes tendentious use of an outdated translation. Whereas Finnis finds a moral stigma in Plato's use of the words "para phusin," which Bury translates as "contrary to nature, ${ }^{, 43}$ Nussbaum finds merely a mild injunction to multiply and replenish the earth. Commenting on the second of the two passages ${ }^{44}$ in which the Stranger characterizes homosexual congress as unnatural, Nussbaum rebuts Finnis's assertion that the term is pejorative by arguing that Plato is merely addressing the issue of the citizens' fecundity:

What does the passage argue? Plato is facing problems of populating a new colony; here as often in the ancient world, underpopulation is a pressing problem, and he is devising legislation to deal with that problem.... He argues that a general prohibition on sex outside marriage will be "conducive to birth," and a toleration of sex outside marriage will be "contrary to birth." Thus the terms tendentiously translated "according to nature" and "unnatural" or "contrary to nature" actually refer ... to "birth" and not "nature" in any normative moral sense. The ambiguity of the word phusis is noted already in Aristotle's Physics, and can be documented from a wide

41. Nussbaum Affidavit, supra note 5, I 10. Nussbaum's reliance here on "Liddle [sic], Scott, _ [sic] Lexicon of the Ancient Greek Language [sic]" to substantiate her claim was later subjected to vigorous attack (charges of perjury, even) by both Finnis and George. On October 27, Finnis submitted an addendum to his rebuttal affidavit to the court in which he pointed out that the lexicon Nussbaum invoked in her affidavit was not actually "the authoritative dictionary relied on by all scholars in this area," but, rather, a long-superseded edition of LidDELL, SCOTT AND JONES, A GREEK-ENGLISH LEXICON. Finnis Addendum to Rebuttal Affidavit, supra note 5, II 5. He adduced this from the fact that both the 1940 and 1968 versions of this work have as their definition for tolmêma the entry "adventure, enterprise, daring or shameless act." Id. Only if one goes back to the 1897 edition can one find an entry that does not include the words "shameless act." Id. Finnis elaborated on these charges in a subsequent article, "Shameless Acts," supra note 7, at 24-29. Nussbaum replied in Platonic Love, supra note 7, at 1531-37, 1614-1622, in which she argued for the general unreliability of lexica for resolving interpretive issues. Not satisfied with her response, George reiterated Finnis's charges in another article, "Shameless Acts" Revisited, supra note 7, at 3237. For an even-handed synopsis of these charges and countercharges, see Mendelsohn, supra note 11. For a more partisan account, see Gerard V. Bradley, In the Case of Martha Nussbaum, 44 FiRST THINGS 11 (1994).

42. Nussbaum Affidavit, supra note 5, II 17. Elaboration on the translation issue can also be found in paragraph 16.

43. Plato, supra note 22, at $636 \mathrm{c}$.

44. Id. at $838 \mathrm{e}$. 
range of texts. ${ }^{45}$

Her point, namely, that the derivation of "what ought to be" from "what is" is anything but straightforward, is elaborated in the subsequent paragraph:

Furthermore, even if we were to... argue that the passage did hold that same-sex relations are "contrary to nature," rather than, as I would argue, "contrary to birth," it makes no moral argument against those acts. Since the fifth century B.C. the Greeks debated about the relative merits of untutored nature and human invention, and they were as well aware as J.S. Mill ("On Nature") that an appeal to nature in the sense of "the way things are without human intervention" doesn't give any argument for their being good. ${ }^{46}$

While Finnis might well be able to establish his claim that sodomy is immoral because it is "contrary to nature," Nussbaum here challenges him to elaborate: "We would need a further argument, since ignorance and disease and all sorts of bad things are 'natural' in some sense." ${ }^{47}$

Aside from the facile projection of the naturalistic fallacy onto Plato, Finnis's major mistake, Nussbaum argues further, is his inability to recognize that Plato's agenda in the Laws is neither the proscription of homosexual congress nor the promotion of faithful conjugal felicity, but, rather, a deep abhorrence of excessive indulgence in corporeal gratification in any form. In his eagerness to find in the Laws both a natural law condemnation of sodomy and a defense of marriage, Finnis fails to note that this dialogue's sexual regulations are actually quite even-handed in their condemnation of all sexual excess, both homosexual and heterosexual.

Nussbaum first makes this case in her affidavit, where she suggests that the problem with homosexuality and adultery is that their sterility is not conducive to the city's growth:

So all that is being said here is, if one wants to increase the population one might well try to do this through a prohibition on extramarital sex. This says nothing at all about sexual acts among non-married people - the entire context is one in which Plato is legislating for the conduct of marriage and the married, and has no bearing on the unmarried. Nor does homosexuality get any condemnation that adultery does not also get.

45. Nussbaum Affidavit, supra note 5, II 54 .

46. Id. \ 55 .

47. Id. 
Furthermore, no special moral praise is given to marriage or married sex; the concern is entirely with populating the new colony. ${ }^{48}$

She shifts her tack somewhat in her subsequent article in the Virginia Law Review, in which she claims that these non-marital sexual practices are condemned on account of their particularly sensual character. While recognizing that it "is sometimes thought that in the Laws Plato offers a general condemnation of homosexual relations in a way that singles them out for special moral blame," she proceeds to argue that "Plato's overall worry is ... about bodily pleasure generally and its ability to take over the personality, disrupting reason." ${ }^{, 49}$ The basic argument, upon which she expounds in an appendix to the article, is the following:

Insofar as Plato devotes particular attention to homosexual relations, it is because he thinks they are especially powerful sources of passionate stimulation, not because they are thought to be especially depraved or shameful. The criticism of those who indulge in the active role is that they are intemperate and overindulgent, not that they are wicked. ${ }^{50}$

As she concludes: "In general, Plato is among the philosophers I consider most suspicious about the bodily appetites." 51 In a lengthy appendix to an already quite lengthy article, Nussbaum seeks to present more ample textual evidence for this claim. ${ }^{52}$

In a summary as brief as the one just presented, one cannot hope to do full justice to the arguments advanced by the various disputants. As those familiar with this case well know, the documents are voluminous, the assertions manifold, and the tone acrimonious. Sifting, sorting, and weighing the debate's various arguments has been taxing indeed. The complexity of this debate notwithstanding, I am confident that I have here conveyed an accurate and essential outline of their disagreement. For Finnis, the Laws' castigation of homosexual intercourse as "contrary to nature" clearly bespeaks Plato's desire to limit sexual relations to the confines of marriage. For Nussbaum, conversely, it makes no sense to speak of "unnatural" sexual intercourse: The sexual crimes proscribed by Plato's Laws lie not in one's choice of partner but in the excessive indulgence in any form of sexual experience.

\footnotetext{
48. Id. II 54.

49. Nussbaum, Platonic Love, supra note 7, at 1579.

50. Id. at 1580 .

51. Id. at 1581.

52. See id. app. 3 at 1623-39.
} 


\section{What Does Plato Say About Sodomy?}

In light of the disagreement concerning sexuality in the Laws, the questions to ask, I believe, are the following. The first is necessarily narrow: Is Plato's use of the term "contrary to nature" (para phusin) at 636c a pejorative characterization of homosexual sodomy? Several broader questions flow from the answer to the first. What is the moral status, in the context of the entire dialogue, of "unnatural" acts? What is this dialogue's view regarding male sexual desire? Is the practice of homosexual congress any worse than the many other varieties of non-marital sexual acts? What legitimate interest does the city have in regulating human sexual activity? Finally, what contribution to our vexed debates concerning (homo)sexuality, the family, and the state could an honest and careful reading of the Laws actually make? Let us address each of these questions in turn.

In their various depositions, testimonies, affidavits, and post-trial articles, Nussbaum and Finnis vigorously argued, as I have elaborated above, about the latter's assertion that Plato characterized homosexual intercourse with the pejorative terms "contrary to nature" (para phusin) and "enormities" (tolmêma). Key to both parties' strategies was ascertaining the precise meaning of these words; to this end they primarily invoked lexica (old and new), alternative translations, and computer-generated word counts. To a lesser extent, they also sought to highlight (or diminish) the syntactical ambiguities and textual flaws in the dialogue's various manuscripts. While this debate presented many curious issues, it suffered, regrettably, from the intellectual myopia with which scholars, especially those who labor with old and complicated texts, are often impaired: They failed to situate their "translations" of these words within either the immediate context of the passage or the broader context of the dialogue as a whole, or did so in a disingenuous manner. Since a slightly more far-sighted perspective is necessary to understand this passage, allow me to attempt to sketch the dialogical context into which Plato thrust these potentially charged words.

One of the most central issues addressed in the Laws is the problem of human pleasure. Over the course of this very lengthy dialogue, the protagonist, a certain unidentified Athenian stranger traveling in Krete, insistently asks the following pertinent questions: What is the relationship of bodily pleasure to human nature? What kind and degree of pleasure is optimal? Finally, to what sort of regulation, both personal and political, should it be subject? While the Athenian is eager to engage in an extended discussion of these questions, particularly the possibility that the moderate enjoyment of 
pleasure -the drinking of wine is his flagship example-is morally preferable to either abstention or excess, he knows that the character of his two interlocutors, a Spartan and a Kretan, inclines them to resist such talk. ${ }^{53}$

This sort of conundrum is, of course, a structural element in every Platonic dialogue. The long-winded protagonist (usually Socrates, but occasionally another) engages one or more interlocutors in a vigorous debate concerning some topic or another. The substance of these discussions is often weighty, and on occasion the reader might even walk away with some formulaic expression of what "Plato thinks" about such and such a matter. More interesting, at least for seasoned readers of these dialogues, is not so much the doctrine one might discern, but the exercise of watching the Socratic protagonist wrestle with his various interlocutors, each of whom appears to us as a manifestation of a certain sort of human soul. (The Republic is, in this respect, exemplary: While the reader might well claim to have learned much about the layout of the "just city" upon coming to the end of Plato's first articulation of a "city in speech," 54 the real excitement comes from watching the responses of the youthful interlocutors to Socrates' attacks on their various conceits.)

In this respect, the Laws conforms well to the Platonic model. Like the Republic, the work it follows, and to a certain extent corrects, the Laws provides us with two other instantiations of the human spirit. The more interesting of the two is Kleinias, an aged statesman from Knossos, the predominant city on the isle of Krete, who has been entrusted by the city elders with the foundation of a colony. A pious man, Kleinias has undertaken a pilgrimage from Knossos up to the mountain-top sanctuary of Zeus, where he hopes, we presume, to obtain revelatory guidance concerning the laws for his colony. Accompanying him on his walk is Megillus, an elderly Spartan with extensive military experience, who appears to be quite knowledgeable about the details of Kleinias' colony. Emigrants from other cities on the Peloponnesian peninsula will also settle in this city. ${ }^{55}$

These men are, as readers of the dialogue soon discover, quite different. Kleinias has traveled more widely, read more curiously, and, it would appear, thought more deeply about the whole range of

53. See Plato, supra note 3, at Books I and II. For an extended discussion of the Laws' treatment of these and other questions, see RANDALL BALDWIN CLARK, THE LAW MOST Beautiful and Best: Medical ARgument and Magical Rhetoric in Plato's Laws (Rowman \& Littlefield - Lexington Books, forthcoming 2001).

54. Plato, Republic (Allan Bloom ed. \& trans., Basic Books 1991).

55. For a more extensive comparison of the protagonists and interlocutors of these two Platonic dialogues, see CLARK, supra note 53, at Chapter 1. 
issues entailed in the foundation and nurture of a healthy city. $\mathrm{He}$ is quite capable of following, step-by-step, as the Athenian leads him in a lengthy and complicated mountain-side conversation. Megillus, however, appears to be less interested in entertaining this Athenian's unusual ideas. In any event, we don't know much about what he actually thinks, as he says very little over the course of this extremely lengthy dialogue.

In spite of their various differences, there is one manner in which they are quite similar: They are both products of the abstemious Dorian culture, one that prides itself on the strict avoidance of all pleasurable activities, including intoxication. In this respect, they are both resistant to the Athenian's advances. Drinking, one of the most accessible and enjoyable of human activities, would be the perfect starting-point for the Stranger's discussion of the problem and promise of pleasure, but as we ourselves can see in the opening pages of the dialogue, these two prove themselves resistant to the Stranger's efforts to raise these issues. Such a discussion would, in fact, constitute a rather substantial criticism of the traditional Dorian lawgivers. ${ }^{56}$

How, then, does the Stranger seek to initiate this titillating, if not seditious, discussion of the virtue-inducing power of wine? As odd as it might appear, he does so by provoking a fight with his interlocutors. While it is a common strategy to win debates by vigorously demonstrating the weaknesses in your opponent's position, such an approach runs the risk of stiffening his resistance. The Athenian seems to be aware of this psychological truth. Instead of launching into a head-on attack on the crabbed character of the Dorian law (an approach that had already raised his companions' hackles), he seeks now to situate himself as a patriotic defender of his native city's own practice of symposia. In the positive role of advocate rather than the negative role of critic, the Athenian better situates himself to advance his subversive argument. By provoking, exacerbating, and then conciliating a nasty little spat, the Stranger puts himself in a stronger position to make the argument that really matters to him. ${ }^{57}$

So how does this tiff proceed? It starts, as does many a playground scuffle, with the charge that the other party engages in frightful sexual practices and then covers them up with other moral crimes. In this case, the Athenian specifically accuses the Dorians of taking

6 .

56. See, e.g., PLATO, supra note 3 , at $628 \mathrm{e}, 630 \mathrm{~d}$. See also CLARK, supra note 53, at Chapter

57. For an elaboration on this rhetorical strategy, see Thomas Pangle, Interpretive Essay, in Plato, LaWs, supra note 3, at 393-96. 
hypocritical delight in the unnatural practice of sodomy and then covering up their vice with a blasphemous lie concerning the gods. The Dorians initially resisted the Athenian Stranger's suggestion that the lawgiver should encourage the virtue of moderation by teaching his subjects to enjoy-but resist the excesses ofpleasurable activities; they had, after all, repeatedly asserted that the Dorian laws do not tolerate the slightest indulgence in corporeal pleasures. In response to these assertions, the Athenian points out that the practice of gymnastics, which his interlocutors had specifically characterized as conducive to the pleasure-denying virtue of courage, also leads to the unnatural vice of sodomy. "There is an ancient law," the Stranger explains, "concerning sexual pleasures not only of humans but of beasts, a law laid down even in nature, which this practice seems to have corrupted. ${ }^{\prime 58}$ The Athenian elaborates this claim with another assertion: Sexual pleasure comes in two forms, procreative natural heterosexual congress and unnatural homosexual union. Natural: "It should be understood that the pleasure is given according to nature, it seems, when the female unites with the nature of males for procreation." ${ }^{\text {99 }}$ Unnatural: "Males coming together with males, and females with females, seems against nature." $" 10$ Important to note, however, is that the Athenian regards both forms of genital intercourse, natural and unnatural, as inherently pleasurable. As the Stranger declares, "the daring of those who first did it seems to have arisen from a lack of selfrestraint with regard to pleasure." ${ }^{61}$ The problem with this Dorian practice, the Athenian suggests, is thus two-fold: Not only is it "unnatural," it is also excessive.

The problem with one vice, the Athenian attack continues, is that it leads to others. Because the Dorian law, as interpreted by even its most thoughtful adherents, categorically condemns the pursuit of pleasure, Kleinias' forefathers - men who had spent their time ogling boys at the gymnasia - had to find a way to justify their hypocrisy. This they did with their blasphemous ascription of the rape of Ganymede to Zeus: "But the fact is, we all accuse the Cretans of being the originators of the myth of Ganymede." ${ }^{\text {2 }}$ According to this story, even the greatest of the gods enjoyed the company of beautiful young men: Ganymede, "who was the loveliest born of the race of mortals," was abducted "to be Zeus' wine-pourer, / for the sake of

58. Plato, supra note 3, at 636b. All passages from the Laws hereafter quoted (unless otherwise noted) are taken from Professor Pangle's translation.

59. Id. at $636 \mathrm{c}$.

60. Id.

61. Id.

62. Id. at $636 \mathrm{~d}$. 
his beauty." ${ }^{63}$ The Athenian pulls no punches with his final, trenchant charge: "Since their laws were believed to have come from Zeus, they added this myth about Zeus so that they could be following the god as they continued to reap the enjoyments of this pleasure." ${ }^{94}$ Translate para phusin and tolmêma however you will, the gist of the Athenian's attack on his interlocutors is unmistakable: Perverts, weaklings, hypocrites, blasphemers!

Megillus is not insensible to the abusive character of the Athenian's comments. After reiterating his assertion that "the lawgiver in Lacedaimon seems to have done what's correct when he ordered fleeing from pleasures," 65 Megillus engages in an equally patriotic ad hominem retort: You Athenians are a bunch of drunkards!

Never would you see in fields or towns under Spartan supervision any drinking parties or any of the stuff that goes with them, which has such power to incite men to every sort of pleasure. There isn't a one of us who wouldn't immediately inflict the gravest punishment when he encountered one of those drunken revelers, and the Dionysia wouldn't afford an excuse that would protect him, if he were doing the sorts of things I saw them do in the carts once among your people. Why, in Tarentum among our colonists I witnessed the whole city drunk at a Dionysia! That kind of thing just doesn't exist among us. ${ }^{66}$

The Athenian then reciprocates by reminding Megillus of the somewhat less-than-irreproachable character of the Spartan ladies. ${ }^{67}$

Lacedaimonian stranger, all such things are praiseworthy, where there is endurance; where that is loosened, they do become pretty stupid. Perhaps someone from our side might defend himself by taking you up, and pointing to the looseness of your women. ${ }^{68}$

When the Athenian again tries to raise the issue of the proper sort of

63. HOMER, ILIAD XX.232-34 (Richmond Lattimore trans., Univ. of Chicago Press 1962).

64. PLATO, supra note 3 , at $636 \mathrm{~d}$.

65. Id. at $636 \mathrm{e}$.

66. Id. at $637 \mathrm{a}-\mathrm{b}$.

67. The Athenian's accusation is not baseless. This charge is echoed in the works of poets as diverse as Homer and Euripides. The former, of course, recorded in detail the war caused by the adulterous Helen, wife of Menelaus, King of Sparta; with somewhat greater pith, the latter has one of his characters declare: "Not even if she wanted to could a Spartan girl be chaste. They leave their houses in the company of young men, with bare thighs and loosened tunics, and in a fashion I cannot stand they share the same running tracks and wrestling places with them." EURIPIDES, ANDROMACHE 597-600 (David Kovacs ed. \& trans., Loeb Classical Library 1995).

68. Plato, supra note 3 , at $637 \mathrm{~b}-\mathrm{c}$. 
wine-drinking ("So let's speak at greater length about the whole subject of intoxication"69) and points to the many warlike racesScythians, Persians, Carthaginians, Celts, Iberians, and Thraciansthat engage in some version of the practice, Megillus belligerently replies: "But, $\mathrm{O}$ best of men, we do put all these peoples to flight when we take up our arms."70 The bloodied contour of this combative conversation is unmistakable: Faggot, souse, bastard, wimp! This is hardly an exchange best rendered by translation into morally "neutral" English.

At this point, the Stranger begins a strategic retreat from his attack. Rather than respond to Megillus' bombastic provocation, the Athenian asks him to consider the possibility that drinking (like the various other practices with which they have respectively charged each other) might well be praiseworthy, if properly governed. As he declares to Megillus: "Having heard only this much about the subject of drunkenness, some of us are immediately blaming it and others are praising it-both absurdly." ${ }^{\prime 1}$ Instead of engaging in this debilitating battle ("I don't think it makes sense for us to go through each of the other legal customs this way" ${ }^{\prime \prime}$ ), he proposes that they "go through this very custom, drunkenness" "73 with the broadmindedness and civility that might serve as a model for the entire day's inquiry. Megillus' resistance softens and the Stranger proceeds with his advocacy of well-governed drunkenness, a subject that will occupy them until the end of the second book.

Our brief analysis of the spat between the Athenian Stranger and Megillus, his Spartan interlocutor, should equip us to adjudicate another: that between John Finnis and Martha Nussbaum over the dialogue's assessment of homosexual congress. While Finnis and Nussbaum vigorously quibbled over the precise translation of the terms para phusin and tolmêma at 636b-c, a modest effort to understand their context unmistakably reveals that the Athenian's unflattering characterization of sodomitic congress is part of a deliberate (and successful) campaign to rile his interlocutors. Nussbaum should not be the least bit surprised that almost all published translations of the Laws render these expressions, respectively, with the disparaging terms "contrary to nature" and "enormities." The English is tendentious precisely because the Greek is also.

\footnotetext{
69. Id. at $637 \mathrm{~d}$.

70. Id. at $638 \mathrm{a}$.

71. Id. at $638 \mathrm{~d}$.

72. Id. at $638 \mathrm{e}$.

73. Id.
} 


\section{UNNATURAL ACTS: A SECOND GLANCE}

With Plato, however, few things are as simple as they first appear. As any semi-sentient reader well knows, his sparkling works are suffused with an ironic complexity comprehensible only to those who are willing to pay careful attention to the complete dialectical structure (at the very least) of any given Platonic dialogue. Superficial readings of his work, such as the one I have just presented, provide insights which are just that: superficial.

Particularly fraught with complexity is this dialogue's invocation of the term "nature." Finnis understands, quite correctly, that Plato attacks the Dorian practice of sodomy as "contrary to nature" at 636b-c of the Laws. Nussbaum, perhaps suspecting that her interpretation of this passage is indefensible, insists that this dialogue's invocation of "nature" is so diffuse as to be unilluminating. While Finnis is as correct in his interpretation of 636b-c as Nussbaum is wrong, Finnis should not gloat, nor Nussbaum evade, for a somewhat more careful examination of the Athenian Stranger's invocation of nature in this dialogue will deflate both of their claims.

The concept of "nature" is a tremendously important issue in the Laws. From the beginning to the end of this very lengthy dialogue, Plato forces his reader to ask himself two inescapable questions: What would "natural" politics look like and are such desirable? While I fear that these questions could not adequately be addressed by even a lengthy and erudite book ${ }^{74}$ to comprehend the respective inadequacies of Finnis's and Nussbaum's interpretations of 636b-c it would be useful to understand precisely how Plato raises this issue and then problematizes it, thus setting the stage for the dialogue's consideration thereof.

The importance of this issue is suggested by its exceedingly early occurrence in the dialogue. In the very first sentence; the Athenian Stranger asks his interlocutors whether it is "a god or some human being, strangers, who is given the credit for laying down your laws?"75 $\mathrm{He}$ receives two contradictory responses. The initial response comes from Kleinias, the elderly Knossian statesman who has been entrusted with chief responsibility for founding a new Kretan colony, who reports the traditional Dorian belief that the law has a divine origin: It comes from a "god, stranger, a god - to say what is at any rate the most just thing." "' Kleinias' suggestion that man finds law by looking to the heavens is underscored by the destination of this

74. For a modest attempt at such, see CLARK, supra note 53.

75. Plato, supra note 3 , at 624 a.

76. Id. 
prospective lawgiver's trek-the mountain-top cave sanctuary of Zeus.

On the other hand, even as Kleinias avers by deed, if not also by word, that the laws have a divine origin, his response to the Stranger's next question suggests that their source may be rather more mundane. When the Stranger asks why these divine laws ordain common meals, gymnastic training, and archery, Kleinias seeks to demonstrate how "all of these practices of ours exist with a view to war." 77 He first explains that the Kretans deploy lightly armored infantry archers in warfare because the mountainous "nature" (phusis) of the Kretan terrain will not permit the use of more heavily armored cavalry, as is customary in Thessaly, where the flat plains are conducive to equestrian battle. Kleinias next argues that the civilian practice of common meals is derived from the fact "that all men, when on a military campaign, are compelled (anankazontai) by the business to eat together during this time in order to keep up their guard." ${ }^{78} \mathrm{He}$ concludes his response with an assertion that peacetime laws should replicate those of war because "for everyone throughout the whole of life an endless war exists against all cities." established all our customs, public and private, with a view to war, and ... he handed down the laws to be guarded according to these principles." $" 80$

Let us consider more carefully some of the assumptions and implications of this remarkable defense of Kretan law. While Kleinias initially insisted that Kretan laws come from god rather than man, his answer to the Stranger's next question shows Kretan law (or at least his understanding thereof) to be thoroughly earthbound. All customs, public and private, are ordained for the sake of success in war-and war is pursued to acquire and retain bodily goods, not the least of which is corporeal self-preservation. It is worthy of note that in his response Kleinias introduces into the dialogue here two words, phusis (nature) and anankê (necessity or compulsion), which are of profound significance both in pre-Socratic philosophy and in this dialogue. One of the major achievements of the pre-Socratic philosophers was a concept of "nature," which they juxtaposed to "law" or "convention" (nomos) and to "art" (technê). Nature, because it is ever-lasting and all-powerful, forms the essential context in which all human activity occurs. Crassly put, what nature

77. Id. at $625 \mathrm{~d}-\mathrm{e}$.

78. Id. at $625 \mathrm{e}$.

79. Id.

80. Id. at 626a-b. 
demands, man must fulfill. This antithesis was a powerful tool in the hands of certain Sophists, who invoked the primacy of nature to support their rejection of the traditional practices of Greek society. With his invocation of "nature" and "necessity" in his defense of the Kretan law, Kleinias thus reveals himself an unlikely heir to this Sophistic tradition.

But Kleinias' appeal to necessity and nature maintains a certain pre-philosophic naïveté. Unlike these Sophists, who were quick to apprehend the antithetical quality of the relationship between nature and convention, for Kleinias there is no such tension. Kretan law springs up, without intermediation, from that island's rocky soil. Many Sophists saw the contrast between nature and convention; exercising their option, they accepted the former. Kleinias accepts nature without realizing that he has a choice. Kleinias' obliviousness to the tension between the natural and the conventional can best be seen in what he does not say in his discussion of archery and common meals. Not mentioned in his defense of archery is the fact that great shame is associated with this form of warfare. Instead of fighting at close quarters, where the combatants reciprocally expose themselves to the risk of injury, the Kretans kill their enemies from a distance with arrows. ${ }^{81}$ Kleinias speaks of this cowardly practice in a matterof-fact way: The Kretan countryside is mountainous, so the Kretans deploy lightly armored infantry archers, but the land surrounding Thessaly is flat, so the Thessalians fight on horseback. His argument is not one that your run-of-the-mill Sophistic relativist would make, namely, that diversity in customs is indicative only of diversity in preference. He argues, rather, that diversity in human customs, to the extent it exists, is dictated by diversity in nature.

Kleinias' explanation of the origin of common meals is similarly oblivious to the ignominy of this practice. Refined and leisured people dine in the relaxation of their own homes, reclining on soft couches, drinking wine in the company of family, friends, and wellborn strangers. Wartime nutrition resembles, rather, swillish feeding of a particularly brutish sort. If attacked while eating, the soldier must spring from his haunches, replace his armor-his helmet still containing, likely, the remainder of his meal - and engage the enemy in a struggle for his very life. Like his discussion of archery, Kleinias' explanation of the origin of their common meals reveals a straightforward matter-of-factness. The practice of taking meals in

81. See also id. at 706c-d. Here, the Stranger's contempt for such mobile combat prompts him to express his gratitude that the Knossian colony is not endowed with a good harbor. On the Greeks' contempt for the cowardice of the bowman, see Diomedes' reproach to Alexandros after the latter shot an arrow at him from behind a column. See HOMER, supra note 63 , at XI.385-95. 
common, like archery, arose from the necessities of warfare. For Kleinias, these necessities are so compelling that he has difficulty imagining that the Kretans would want to fight or eat in any other manner.

While Kleinias appears to be a character of sound intellectual powers compared with the Platonic interlocutors whom Socrates frequently leads around like ring-nosed bull calves, he reveals himself, upon probing, to be insufficiently reflective. His intellectual incoherence can best be seen in his confusion concerning the origin of law. To the Stranger's first question, Kleinias asserts that the law comes from "a god, stranger, a god." Nonetheless, when he tries to give a detailed explanation of this divine law, it becomes apparent that the law is oblivious to the virtues of the soul. The Kretan law, like the human bodies it governs, is thoroughly enslaved to the corporeal necessities of nature. Kleinias does not recognize that a god-if a divinity actually is the source of Kretan law-would cultivate the higher virtues of the soul rather than the lower ones of the body. Kleinias is, to be sure, an amazingly intelligent and quickwitted interlocutor, as can be seen in the vigor with which he follows the Stranger's argument. Nonetheless, as the dialogue begins, he is as yet unaware of the various ways in which the divine and the natural, the soul and the body, can be at odds with each other.

The Athenian Stranger's most evident rhetorical objective in this dialogue is to teach Kleinias, a man who will shortly give laws to a new colony, to free himself and his city from the necessities of nature. In order to do so, the Stranger must first make him aware of the tensions between the soulful and the natural. He must then persuade Kleinias to promulgate laws that will elevate the former over the latter. They will not be like the Kretan laws, which slavishly conform to the perceived necessities of the body. In short, the Athenian desires to open up the law to the influence of Socratic philosophy.

The Athenian, however, does not engage in a frontal assault. As part of his effort to forge tempered truth from the molten opinions of the many, this Platonic philosopher starts with his Dorian interlocutor's unphilosophic practices and the base desires from which they originate, then seeks to derive legislation ultimately more conducive to the philosophic virtues of the soul than the earth-bound scrambling codified by the necessitous Dorian law. Over the course of this dialogue, the Athenian systematically takes up, examines, critiques, and modifies many of the practices regulated by the Dorian law; in each instance, he takes a custom derived from private desire and subtly 'transforms it into a public good. While the Stranger's adventures in philosophic legislative rejuvenation touch upon almost 
every aspect of his interlocutors' laws, in no area are his efforts more visible than in his transformation of laws governing three of the basest human desires: those for food, drink, and sex. ${ }^{82}$ Because the issue at hand is precisely Plato's view of homoerotic desire and the family, let us take a careful look at the Athenian's understanding of both the nature of erotic desire and the soulful elevations to which he subjects it.

\section{PROMISCUITY AND NARCISSISM: WHICH IS THE GREATER PROBLEM?}

Rather baldly stated, the Athenian Stranger's view of male sexual desire is that men are both sexually promiscuous and romantically narcissistic. Men, especially those still young, seek out frequent opportunities for sexual intercourse, preferably with partners very much like themselves, be it in terms of class, disposition, kinship, or gender.

The first of these claims, that the Athenian Stranger views male sexuality as fundamentally promiscuous, is unremarkable, both textually and ontologically. Not only does the Laws provide ample illustration of youthful remonstrances at the attempt of the elderly to drive adolescent sexual desire into the confines of lawful matrimony, ${ }^{83}$ few (with perhaps the exception of our postmodern brethren) would seriously gainsay the biological basis of the sevenyear itch.

The second of these claims, that Plato here portrays sexual desire as narcissistic, is less immediately apparent. Modern theorists of evolutionary psychology would not be at all surprised by Plato's assertion that the human male is not exactly hard-wired for conjugal fidelity; his suggestion, however, that men by nature prefer the strokings of their sisters and favors of their fellows over those of their wives would strike many, at the very least, as quite questionable.

Nonetheless, over the course of this weird dialogue Plato does indeed paint a portrait of youthful male sexuality that is highly suggestive of this perspective. Although his explicit declarations of such are somewhat oracular ("it is according to nature that everyone always be somehow attracted to what is most similar to himself" ${ }^{\prime 4}$ ), as the Stranger seeks to woo coltish young men into the institution of marriage he provides the reader with multiple and colorful examples

82. See ClaRK, supra note 53, at Chapters $4,7$.

83. See id. at Chapter 1.

84. Plato, supra note 3 , at $773 \mathrm{~b}$. 
of the promiscuous and narcissistic nature of male erotic desire.

One of the most remarkable features of the debate between Nussbaum and Finnis over the relationship between homosexuality and marriage in the Laws is their complete silence on many of the passages in which the Athenian Stranger addresses the issue of marriage itself. In addition to the omnibus legislation in Book VIII (over which Finnis and Nussbaum vigorously strove) proscribing the practices of masturbation, adultery, and homosexual intercourse ${ }^{85}$ the Athenian pays a great deal of attention elsewhere to the realization of the legislator's desire that young men and women form the stable and loving marriages necessary for the rearing of healthy and well-rounded children. Not only will his laws allow Magnesia's youth to satisfy their prurient curiosity concerning potential mates' anatomical (im)perfections (a staple of the city's various religious festivals is youthful dancing sans toga), ${ }^{86}$ the Athenian provides the city's lusty young men with more than ample guidance on the moral and economic criteria they should consider in their selection of a mate. His eagerness to offer such guidance can be discerned in the fact that he sees fit to offer, alongside many lines of advisory dicta, not one but two formal marriage laws, in which he exhorts young men to assume the onerous burdens of marriage and fatherhood.

A cursory examination of the first of these two laws is suggestive of the challenge facing the lawgiver. Most striking is its location. This particular law appears at the end of Book IV, immediately after the Stranger introduces his innovative "double method" one in which violently compulsory edicts are preceded by gently persuasive preludes. ${ }^{88}$ Recognizing that the lawgiver's commandviz., that the young man "marry after he reaches the age of thirty and before the age of thirty-five" $" 89$ and thenceforth "care for children and a wife" $"$ - will encounter resistance from those capable of counting the costs of fatherhood (both financial and psychic), the Athenian

85. See id. at $838 \mathrm{e}-839 \mathrm{a}$.

86. The Athenian explains:

For indeed, with regard to the community and commingling of those who are married, it is necessary to dispel the ignorance concerning the bride's people, the bride herself, and the people to whom they are giving her. Everything possible must be done, to the best of one's ability, to prevent any mistakes at all being made in such affairs. To achieve such a serious goal, play must be devised that consists of choral dancing by the boys and girls, where they can see and be seen, in a reasonable way and at an occasion that offers suitable pretexts. Both sexes should be naked, within the limits a moderate sense of shame sets for each.

Id. at 771e-772a.

87. Id. at 720e. See also CLARK, supra note 53, at Chapter 4.

88. See PlATO, supra note 3, at 718a ff.

89. Id. at $721 \mathrm{~b}$.

90. Id. at 721c. 
pronounces a "prelude" in which he seeks, rather, to appeal to the self-interest of these selfish young men. The bait he dangles before their eyes is their interest in eternal greatness. As he acknowledges, "it is the nature of everyone to desire immortality in every way." But instead of emphasizing the tried and true methods for achieving such-renown in athletics, warfare, politics, and art-the Athenian argues that "by leaving behind the children of children" the ambitious young man can gratify his "desire to become famous and not lie nameless after [he] has died." 92 The Stranger well knows that committing the self-centered young man to the other-regarding institutions of marriage and fatherhood requires that the lawgiver provide him with a vastly expanded concept of self.

While the first of the Stranger's two marriage laws hints at the grounds for the young man's opposition to marriage (viz., his recognition "that the bachelor's life is a source of gain and ease for him" "93), the second law reveals even more clearly the selfish character of male sexual desire. This law (pronounced a bit later in Book VI) presumes that the first has been successful: It addresses the young man who "has found someone who pleases him and is appropriate for sharing and procreating children." recognizes, however, that the willingness of the young man to commit himself to the ostensibly other-regarding institution of marriage is far from the self-abjuration the legislator desires.

This can best be seen in the vast discrepancy between the respective benefits that the lawgiver and the groom hope to obtain from marriage. For his part, the young man follows nature's dynastic dictate: Should he desire to marry, the woman of choice is one whose offspring will, in every possible way, resemble their sire. As the domineering possessors of recessive genes have long suspected, the surest guarantee of auto-replication-apart from cloning-is to marry a woman like oneself. Therefore, if a groom, being himself great, loves virtue, he will seek a woman of accomplishment; if he, being courageous, loves valor, he will seek a woman of a hasty disposition; if he, being handsome, loves beauty, he will seek a comely woman; and if he, being of a renowned family, loves his clan, he will seek a woman from among his kin. As the Athenian Stranger observes: "It is according to nature that everyone always be somehow attracted to what is most similar to himself."

91. Id.
92. Id.
93. Id. at $721 \mathrm{~d}$.
94. Id. at $772 \mathrm{~d}$.
95. Id. at $773 \mathrm{~b}$. 
aberration in the Greek erotic imagination that the name "Justice" was given to a certain Pharsalian mare, each of whose foals bore the exact likeness of its respective sire. ${ }^{96}$ The strength of this desire for self-replication-and the obstacle it poses for philosophic lawgivers - can be discerned by recalling that Socrates' Kallipolis foundered, in part, on the abolition of private paternity and therewith the father's natural hope that he might yet locate in his infant son's face the only sure sign of immortality the taciturn gods seem willing to offer to common mortals. ${ }^{\text {? }}$

The lawgiver, however, desires that the offspring of his citizens' marriages be, in terms of their talents, dispositions, and genetic composition, in every way moderate. Translated into suburban argot, they should be well-adjusted and well-rounded children. Speaking for the lawgiver in the prelude to his second marriage law, the Stranger thus counsels the young man (who, unlike his profligate peers, "has grown from good parents" 98 and desires to marry) "not to avoid someone of poor parents nor to pursue especially someone of rich parents, but, other things being equal, always to give precedence in honor to the less highly placed of your prospective partners." ${ }^{99} \mathrm{He}$ goes on to advise that a "man who knows himself to be too impatient and hasty in all his affairs should be eager to become related by marriage to orderly parents, and one whose natural disposition is the opposite should proceed to ally himself with the opposite sort of in-laws." ${ }^{100}$ For, as he notes, it is in the interest "of the hearths that are being united" for the offspring of these marriages to be "even-keeled and ... commensurable."101

At least from the lawgiver's perspective, the more compelling reason for the formation of such unions is, however, the tremendous peril presented to the city by the human predisposition to conjoin with one's own: "the city as a whole becomes uneven as regards wealth and the dispositions of characters." ${ }^{102}$ Wealthy, beautiful, and accomplished parents will, if experience be any guide, produce wealthy, beautiful, and accomplished children; poor, ugly, and luckless parents will produce poor, ugly, and luckless children. "Wish[ing] to avoid for ourselves" the consequences of the familial perpetuation of financial and moral inequality, which are, the

96. See ARISTOTLE, supra note 4 , at 1262a26.

97. See PLATO, supra note 54, at V.449a-480a; see also Allan Bloom, Interpretative Essay, in id. at 379-89; PLATO, supra note 3, at 739c-744a; CLARK, supra note 53, at Chapter 5.

98. Plato, LAwS, supra note 3, at 772e-773a.

99. Id. at $773 \mathrm{a}$.

100. Id. at $773 \mathrm{~b}$.

101. Id. at $773 \mathrm{c}$.

102. Id. at 773b-c. 
Stranger reminds us, "very prevalent in most cities," 103 he thus declares the following match-making principle: "Let there be one myth regarding marriage: in each marriage what must be wooed is not what is most pleasant for oneself, but what is in the interest of the city. $" 104$ While the Stranger began the dialogue with a declaration regarding the politically pernicious character of sodomy, this second marriage law suggests that the homosexual's self-love is but a particularly outrageous instance of the entailed political inheritance that the erotic human's sexual narcissism can bequeath to his city.

The issues raised in the Athenian's defense of his second marriage law provide us with an opportunity to reflect on the debate with which this essay began: What, in fact, does Plato say in this dialogue about the naturalness of homosexuality and its relationship to the family? What we find is that both antagonists grossly misread the Laws, to the detriment of their respective arguments. Concerning the "unnatural" character of sodomitic congress, Finnis claims to find a consistent condemnation of homosexual acts as unnatural, while Nussbaum asserts that the term "natural" is too ambiguous to be morally meaningful. Our analysis of the second marriage law suggests, rather, that both are wrong. Not only does the Stranger here characterize the sexual attraction of like-to-like as "natural," he also vigorously seeks to repress all forms of man's natural sexual narcissism on this very basis. Nature matters greatly, but in a way that neither perceives. Concerning the Stranger's defense of the family, Finnis finds in the Laws a vigorous advocacy of the moral centrality of wedded love, while Nussbaum argues that it is carnal excess, not gender misfit, that is the source of the Laws' antipathy (if any can be found) to the practice of sodomitic congress. Our analysis of the second marriage law suggests, again, that both are wrong. While the Stranger is quite clearly intent on repressing sexual narcissism in all its forms in order to establish stable households for the rearing of measured children, it is anything but clear that this is a ringing defense of the moral import of monogamous marriage. Though he enthusiastically encourages the formation of families, the vigor of the Athenian's advocacy appears to proceed more from reasons of state than from moral imperatives of any sort.

\section{THE ART OF RHETORIC: AN ANCIENT "BEHAVIOR MODIFICATION" THERAPY}

The state's interest in repressing-albeit gently-both the 
narcissistic and promiscuous nature of male sexual desire can best be seen in the Stranger's discussion of sexual matters in Book VIII. As we have already seen, the marriage laws presented in Books IV and VI point the reader's attention to the political problems occasioned by these aspects of male sexual longing. In these two passages, however, the Stranger does little more than note the deleterious consequences of this passion and suggest the futility of legislating against it. As the Athenian notes near the end of his discussion in Book VI:

To enact by law, through discourse, that a rich man is not to marry from the rich, and a man capable of doing many things is not to marry someone similar to himself - and to compel those of hasty dispositions to join in marriage with those who are more phlegmatic, and the more phlegmatic with the hastybesides being laughable, would stir up the spiritedness of many. ${ }^{105}$

In Book VIII, however, the Athenian explicitly addresses how the intelligent legislator can redirect - for the benefit of both families and the city-the destructive sexual proclivities of idle men and women: fornication by the young, adultery by the middle-aged, pederasty by the old, and incest by all.

This far-ranging discussion begins with a particularly plaintive lament. Although the Stranger has just concluded his musical and gymnastic legislation, which he presented as the educational pillars of his legislative project, he notes that the difficulty of implementing them pales into insignificance when compared with the task of regulating the citizens' libidos. Concerning education, not only is it easy, he declares, "to know how these and other such matters should be put in lawful order," the city "would neither gain much nor suffer much of a penalty" were they "altered here and there." 106 But concerning the citizens' sexual behavior it is both difficult to obtain compliance and vitally important that the lawgiver gain such: "But there are other matters which make no small difference, about which it is difficult to be persuasive, and which are in fact the task of the god, if it were somehow possible to get the orders themselves from him." "107 Lacking a divine solution, the Stranger pines for "some daring (tolmêrou) human being" who would be willing to speak "before an audience of corrupt souls,... order[ing] what is fitting and becoming to the whole political regime; opposing the greatest

105. Id. at $773 \mathrm{c}$.

106. Id. at $835 \mathrm{~b}-\mathrm{c}$.

107. Id. at $835 \mathrm{c}$. 
desires, and having no human ally, all alone he will follow reason alone." 108

Should such an outspoken man arise in the Stranger's city, he will find, much to his surprise, that these well-educated citizens might then prove to be more difficult to restrain than even their most randy neighbors. As the Stranger explains to his uncomprehending interlocutors, the Magnesian citizens' promiscuity is in fact exacerbated by this city's greatest virtue, its victory over necessity:

When I arrived, in the course of the argument, at education, I saw young men and young women mixing together affectionately. As might be expected, a fear came over me as I reflected on the problem of how someone will manage a city like this, in which young men and women are well reared, and released from the severe and illiberal tasks that do the most to quench wantonness; and where sacrifices, festivals, and choruses are the preoccupations of everyone throughout their whole lives. How, in this city, will they ever avoid the desires that frequently cast many down into the depths, the desires that reason, striving to become law, orders them to avoid? ${ }^{109}$

The Stranger does hope that certain aspects of their education will "predominate over the mass of desires." ${ }^{110} \mathrm{He}$ elaborates: The "fact that it's impossible to get terrifically rich," the moderation taught by the youths' teachers, and the "trained eye of the rulers" should all serve "to limit the other desires as much, at least, as is humanly possible." $111 \mathrm{He}$ ultimately recognizes, however, that this educationally induced moderation is unlikely to overpower the eros of the overprivileged offspring of the city's leisured classes:

But with regard to the erotic love of and for children-both male and female - and the erotic love of women for men and of men for women, whence tens of thousands of things have happened to human beings in private and to whole cities, how could one take proper precautions?"12

He laments in conclusion: "And what sort of medicine will one apply, in each of these cases, so as to find an escape from the danger?" 113

The answer to this question is first suggested at the end of the

108. Id.

109. Id. at $835 \mathrm{~d}-\mathrm{e}$.

110. Id. at $835 \mathrm{e}-836 \mathrm{a}$.

111. Id. at $836 \mathrm{a}$.

112. Id. at 836a-b.

113. Id. at $836 \mathrm{~b}$. 
Stranger's brief but complicated attempt to elevate the Dorian predilection for homosexual pederasty into a high-minded form of educative mentorship. The real problem with the former practice is that, on account of its exclusive emphasis on the pederast's selfish gratification of his bodily pleasures, it does not "help us promote virtue." ${ }^{\prime 14}$ The deleterious consequences of the pederast's desire to "pick the bloom of youth" are realized in both the lover and the beloved alike: The pederast should be condemned for his "softness" in "giving in to the pleasures," being "incapable of mastering them," while the boy, for his part, is also to be reproved for "undertak[ing] the imitation of the female." take the "man who loves the body, hungering for the bloom as for ripe fruit, [who] bids himself take his fill without honoring the disposition of soul of the beloved,"116 and modify his desires such that he can derive pleasure from the chaste admiration and promotion of the virtuous boy. Such a lover, the Stranger asserts, would hold

the desire for the body to be secondary; looking at it rather than loving it, with his soul he really desires the soul of the other and considers the gratification of body by body to be wantonness. He holds in awe and reverence what is moderate, courageous, magnificent, and prudent, and would wish to remain always chaste with a beloved who is chaste. ${ }^{117}$

The Stranger here suggests that by appealing to these higher pleasures, the same instinct that motivates the wayward scoutmaster to furtively sodomize his many charges can be transformed into the well-wishing respect that a noble teacher publicly pays to his most gifted student.

The Stranger's strategy here parallels in a remarkable way his earlier efforts both to introduce women into the city's common meals ${ }^{118}$ and to persuade young men to marry: He takes a relatively necessitous Dorian custom (such as their common meals and selfish fretting for immortality) and transforms it into a considerably more liberated practice by means of persuasive arguments. In the two previous cases, the Stranger had merely suggested that popular resistance to his painful transformations can best be overcome, not by bald-faced coercion, but by means of enchanting song. In the case at hand, however, the Athenian unveils the precise character of this

114. Id. at $836 \mathrm{~d}$.

115. Id. at $836 \mathrm{e}$.

116. Id. at $837 \mathrm{c}$.

117. Id. at $837 \mathrm{c}$.

118. See ClARK, supra note 53, at Chapter 7. 
persuasion. In the face of popular resistance to the lawgiver's salutary efforts to ameliorate the politically and personally destructive consequences of the private pursuit of pleasure, the lawgiver must craft his words in such a manner as to present the healthy but disagreeable choice as the most pleasant. ${ }^{119}$

This is neither easy nor certain, as the Stranger himself witnesses. Megillus, for one, readily succumbs to his blandishments. After concluding the argument with the determination that the law should forbid those exploitative forms of homosexuality in which the pederast does not "desire that the youth become as excellent as possible," the Stranger obtains the enthusiastic assent of "Megillus, my friend." 120 The Stranger's appeal to the superior pleasures of the mentor's pride over the bugger's self-gratification has succeeded in moving at least one dirty old man to consent to this law. The Stranger suspects, however, that Kleinias remains unmoved by these arguments, and promises Megillus that he will return with stronger medicine for their friend:

It looks like-as I guessed-I've obtained your harmonious assent, dear friend. I don't need to inquire what the law among your people thinks about such things-it's sufficient to accept your agreement to the argument. Later on I'll come back to these same matters and try to use incantations to persuade Kleinias. ${ }^{121}$

Before doing so, the Stranger begins an extended exposition of the amazing art of persuasion that has moved one and by which he hopes to move yet others.

The Athenian Stranger's legislative goal regarding his citizens' sexual activity is relatively straightforward: He desires, like most lawgivers, to redirect men's polymorphous erotic energy toward the conception and rearing of healthy children in stable and loving households. By persuading them to abstain from sodomy ("intercourse with males"122), infanticide ("the deliberate killing of the human race"123), masturbation ("the wasting of sperm on rocks or stones where it will never take root and generate a natural offspring"124), and adultery ("abstaining from any female field in which you wouldn't wish your sperm to grow"125), the Stranger

119. See id. at Chapters 2,6,7.

120. PLATO, supra note 3 , at 837 d.

121. Id. at $837 \mathrm{e}$.

122. Id. at $838 \mathrm{e}$.

123. Id.

124. Id. at $839 \mathrm{a}$.

125. Id. 
anticipates that "tens of thousands of good things would result": ${ }^{126}$

It will prevent erotic frenzy and madness, as well as all adulteries, and all excessive drinking and eating, and will make men familiar with and dear to their own wives. Indeed, there are very many other good things that would come to pass, if someone had enough control to pass this law. ${ }^{127}$

To enact this legislation, a rather tall order for even the most single-mindedly puritanical of lawgivers, the Stranger repeatedly boasts here of his possession of a powerful rhetorical art: "In regard to this law I had an art that would promote the natural use of sexual intercourse for the production of children." 128

To illustrate the power of this art, the Stranger attempts to show how it, or something quite like it, is capable of eradicating the human desire to commit incest, the most politically destructive of sexual practices. As the Stranger has repeatedly asserted and demonstrated, when it comes to sexual matters the attraction of like to like has deleterious effects on civic unity: The marriage of wealthy men to heiresses breeds dynasties and the coupling of men to boys fosters factions. ${ }^{129}$ But no sexual union (at least prior to the invention of human cloning) is more conducive to this narcissistic parthenogenesis than the reproductive conjunction of brother with sister and parent with child. . $^{30}$

But with respect to incest-unlike all the other sexual practices the Stranger has thus far considered, compromised, or condemned - the

126. Id.

127. Id. at $839 \mathrm{a}-\mathrm{b}$.

128. Id. at 838e; see also id. at 838a and 839c.

129. The contested passage with which the debate between Finnis and Nussbaum began makes an oblique reference to the political consequences of homosexual love: "So it is with these gymnastics and common meals: in many other ways they now benefit cities, but in the event of civil strife they are harmful (as is shown by the examples of the Miletian, Boeotian, and Thurian boys)." Id. at 636b. For bibliographic references and a brief discussion of these civil wars, see Pangle, Notes to PLATO, supra note 3, at 515 n.34.

130. Pausanias explains the "narcissistic" character of the conjunction of brother with sister in this manner:

On the summit of Helicon is a small river called the Lamus. In the territory of the Thespians is a place called Donacon (Reed-bed). Here is the spring of Narcissus. They say that Narcissus looked into this water, and not understanding that he saw his own reflection, unconsciously fell in love with himself, and died of love at the spring.... There is another story about Narcissus, less popular indeed than the other, but not without some support. It is said that Narcissus had a twin sister, they were exactly alike in appearance, their hair was the same, they wore similar clothes, and went hunting together. The story goes on that Narcissus fell in love with his sister, and when the girl died, would go to the spring, knowing that it was his reflection that he saw, but in spite of this knowledge finding some relief for his love in imagining that he saw, not his own reflection, but the likeness of his sister.

PAUSANIAS, DESCRIPTION OF GREECE 9.31.7-9 (W.H.S. Jones ed. \& trans., Loeb Classical Library 1935). 
lawgiver does not find himself at perpetual loggerheads with the hedonistic masses. And why not? Potentially the most powerful of sexual desires, the yearning of a young man for his sister, the possessor of a genetically similar but complementarily gendered body, has been eviscerated by the pronunciation of a few powerful words: "These things are not at all pious, but are hateful to the gods and the most shameful of shameful things." ${ }^{\prime 13}$ To demonstrate the power of this phenomenon, the Stranger sets a little trap for Megillus. After boasting that he, by virtue of "a certain art,"132 can implement these various sexual regulations, the Stranger elliptically alludes to an amazing case of erotic restraint: "Presumably, we know that even at the present time most human beings, however lawless they may be, nevertheless punctiliously refrain from intercourse with beautiful persons, and do so not involuntarily, but with the greatest possible willingness." ${ }^{\prime 133}$ After Megillus wonders under what circumstances this might occur, the Athenian reveals that he is speaking of incest:

When the beautiful person is one's brother or sister. Moreover, with regard to a son or daughter, the same unwritten law guards in a very effective way, as it were, against touching them-by open or secret sleeping together, or by any other sort of embracing. In fact, among the many there isn't the slightest desire for this sort of intercourse. ${ }^{134}$

Most amazing of all, the Stranger goes on to say, is that this remarkable instance of voluntary forbearance is the result of a few little words: "And isn't it just a little phrase that quenches all such pleasures?" 135 As he elaborates:

Isn't the cause the fact that no one ever says anything else, but from the moment of birth each of us hears people saying these things, always and everywhere? In jokes and in every serious tragedy isn't it frequently said, and when they bring on Thyestes-figures or certain Oedipuses, or certain Macareuses, who secretly have intercourse with their sisters, isn't it seen that they promptly inflict upon themselves the just punishment of death for their crime? ? $^{136}$

The words of the poets, repeated by the masses, are infinitely more

131. Plato, supra note 3 , at $838 \mathrm{~b}-\mathrm{c}$.

132. Id. at $838 \mathrm{a}$.

133. Id.

134. Id. at $838 \mathrm{~b}$.

135. Id.

136. Id. at $838 \mathrm{c}$. 
effective in restraining these sexual desires than the most strongarmed legislation could ever be. As the Stranger concludes,

when a lawgiver wishes to enslave a certain desire which especially enslaves human beings, it's easy to know, at least, how he should handle it. By having everyone-slaves, free men, children, women, the whole city in agreement together-hold this pronouncement to be something sacred, he will have succeeded in making this law very firm. ${ }^{137}$

When the Stranger first announced his possession of this art, the reader was presented with ample evidence regarding the difficulty of its successful implementation. Not only did Plato demonstrate that the Stranger's two interlocutors, likely partakers of a certain Dorian vice, responded to the Athenian's fanciful advocacy of a higher form of pederasty with differing degrees of enthusiasm, but he also had the Stranger forthrightly declare that, though the phrases are little, the pronunciation thereof is anything but straightforward. As the Stranger declares to Megillus: "In order to establish this law, I have now a certain art, which will be in one respect easy to employ but in another respect extremely difficult in every way." 138 These difficulties emerge with greater clarity as the Stranger progressively unveils the operations of this art. The first objection comes from Megillus. Although he acknowledges the power of popular opinion, ${ }^{139}$ he expresses doubts about the possibility that the lawgiver's art might yet make him an arbiter thereof: "But now how will it ever be possible to arrange things so that everyone is willing to say such a thing ... ?" 140 The second is the vicariously expressed rage of the dialogue's young reader, whom the Stranger conjures up after concluding his proud description of the domestic bliss that will flow unto his city's inhabitants: "But if there were standing here some vehement young man full of a lot of sperm who had been listening to the laying down of the law, he would probably revile us for setting up mindless and impossible customs, and would fill the air with his clamor." ${ }^{\text {141 }}$ No stranger to sexual repression, the old man is eager to employ the Athenian's art and lacks only the assurance that it will in fact work; no friend of conformity, especially that which impinges on his jealously guarded amatory prerogatives, the young man fears its implementation.

137. Id. at $838 \mathrm{~d}-\mathrm{e}$.

138. Id. at $838 \mathrm{a}$.

139. See id. at $838 \mathrm{~d}$ ("You are quite correct to this extent: when no one ever even tries to breathe against the law in any way, then the pronouncement has an amazing power.").

140. Id. at $838 \mathrm{e}$.

141. Id. at $839 \mathrm{~b}$. 
The Athenian Stranger proves himself to be remarkably sensitive to these charges. As well he should be! If anything, he has grossly overstated his case: Not only does he make the improbable assertion that ineffable blessings will flow unto those men who suffer the tedium (so it is said) of lifelong heterosexual monogamy, he knows that the intelligent observer can entertain reasonable doubts as to the practicality of his methods, if not the rationality of his aims. To prove his assertions, the Athenian calls to our attention two examples of the human triumph over short-term pleasures for long-term benefits. The first is the Dorian lawgivers' institution of common meals. While "it's not believed that an entire city can live practicing this throughout its life," 142 the Stranger points out that "the disbelief was refuted by the deed, by the fact that it actually came to pass among your people." ${ }^{143}$ In a nod to his earlier (and elliptical) discussion of the inclusion of women in this practice, ${ }^{144}$ the Stranger here suggests that it is this art that will in fact accelerate their integration. ${ }^{145}$

The second is the sexual forbearance of athletes for the sake of victory. To demonstrate "that it is not beyond human ability, but is in fact possible"146 for the lawgiver to obtain compliance to his law, he invokes the examples of several renowned athletes. One of these is Iccus of Tarentum, a man who "was so filled with love of victory, and possessed in his soul such art, and such courage mixed with moderation, that he never touched a woman-or a boy, for that matter-during the entire time of his intensive training." ${ }^{.147}$ The willingness of this far-sighted man and other athletes, men whose "souls were much less educated than the citizens that belong to me and you" and whose "bodies were much more full blooded,"148 "to refrain from an activity that the many say is happy" for "the sake of victory in wrestling and running and that sort of thing"149 bodes well, the Stranger argues, for the success of his enterprise. If men who are "inferior" to the Magnesian citizens "have shown the capacity to master" these base pleasures for the sake of athletic victory, why should not the well-educated Magnesians also attain "victory over pleasures"? ${ }^{150}$ As the Athenian queries Kleinias, who has begun to

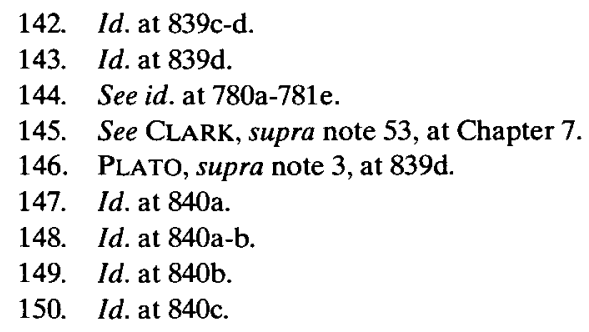


take an interest in this argument, "now will our children be unable to restrain themselves for the sake of a much nobler victory, whose great beauty we will have, it is likely, enchanted them with from the time they were babies, using spellbinding myths, speeches, and songs?"'s1

\section{PRESCRIBING FOR A CIVIC MALADY}

Upon coming to the end of our survey of sexual legislation in the Laws, it is remarkable, at least to this observer, how the actual contour of the rumpled bedscape of Platonic sexuality differs from our expectations. Had we given much credence to the arguments that Professors Finnis and Nussbaum advanced in Evans v. Romer, we would know only that Plato served as Hephaestus for our own cultural wars, forging armaments for the exposed outer flanks in the modern battles against, respectively, iniquity and bigotry. By condemning homosexual intercourse as "contrary to nature," Plato clearly displays - if Finnis's account is to be credited - the prescient instincts of a preternatural advocate of the natural law. On the other hand, by means of a facile declaration of the futility of any understanding of the nature of human sexual desire, Nussbaum interprets the Laws' various attempts at sexual legislation to be prohibitions against the carnal enjoyment of any sexual encounter rather than condemnations of perversity in the choice of partner. Confusing when viewed in tandem, wrong when examined individually, these two analyses were ultimately (and not surprisingly) ignored in Judge Bayless's resolution of the Amendment 2 dispute.

While Judge Bayless appears to have concluded (perhaps rightly) that Plato's Laws-at least as it was presented to him-was not appropriately dispositive of the case at bar, we should not be so quick to conclude that Plato's final reflection on the art of politics has nothing to teach us about the nature of (homo)sexual desire, the weaknesses of the nuclear family, and the city's interest in redirecting the former to thereby sustain the latter. Romer has been decided, but the underlying issue remains. Can Plato help us address it?

Carefully read and properly understood, the Athenian Stranger's sexual legislation reveals that Plato was less interested in serving as an ideological blacksmith than as a privy counselor to statesmen of all ages. Nature and its implications matter immensely for the protagonist of this dialogue, but in a way that both Finnis and

151. Id. at $840 \mathrm{~b}-\mathrm{c}$. 
Nussbaum fail to recognize. Neither a stiff standard for caning nor a formless jellyfish best left floating at sea, the Athenian Stranger's invocation of nature is a deliberate attempt to provoke our reflection on the most difficult and important challenge in political life: encouraging civic hybridization.

This is likely obscured by the fact that the first discussion of sexuality in the dialogue, the disputed passage at $636 \mathrm{~b}-\mathrm{c}$, is in fact an instance of ideological caning: Kleinias, a man who has already declared that the necessities of nature establish the baseline for his understanding of politics, is being intentionally provoked by the Athenian's suggestion that the Dorian penchant for homosexual pederasty might well be "contrary to nature." Once the Stranger has the leisure to talk at length about nature and sexuality (perhaps because the moment of his own agon has already passed), we discover what really concerns him. It is not, as the initial exchange suggested, that homosexuality is unnatural, and hence wicked, but, rather, that there appears to be a natural proclivity for it and all other forms of like-like attraction. As the Stranger declares in Book VI, "[i]t is according to nature that everyone always be somehow attracted to what is most similar to himself."152 Even though this attraction is natural-or perhaps precisely because it is such-the city needs to overcome it. Rather than allow the autonomous functioning of man's natural cupidity to perpetuate the formation of clans and parties - those institutions most adept at preserving and fostering financial inequality and political division - the goal of the far-sighted statesman is to match opposites in marriage: the rich with the poor, the hasty with the orderly, and, lest it be forgotten, the male with the female.

It is this task, the conjunction of dissimilars into a civic unity, that presents statesmen with their greatest challenge. Students of politics well know the ease with which a Machiavellian politician can set one party against another. The Laws seeks to teach its reflective readers to resist precisely this temptation. Instead of encouraging our divisive inclinations, Plato charges his readers, ancient and modern, to understand how disparate elements - of the city, of the soul, and of the human race-can be brought into peaceful community.

Recognizing the resistant misapprehension this suggestion will encounter, particularly with regard to the "commingling that produces children," ${ }^{153}$ the Athenian Stranger invokes at one point in the dialogue a more readily comprehensible metaphor for his objective: the wine-mixing bowl. The Greek drink of choice was

152. Id. at $773 \mathrm{~b}$.

153. Id. at $773 \mathrm{~d}$. 
actually a mixture of two vastly different liquids: concentrated wine and tasteless water. ${ }^{154}$ One dangerous, the other innocuous, prior to consumption they were brought together in the mixing bowl, where the strength of one complemented the weakness of the other: "For it's not easily understood that a city should be mixed, just like the drinker's bowl: The wine, when poured in, is throbbing with madness, but under the chastening of another, sober god, it forms a noble partnership that creates a good and measured drink." 155

In his command to prepare this equanimous beverage, the Stranger does not leave us without the necessary bar-tending tools. For those willing to read the dialogue with care, Plato presents not only abundant indication of both the promiscuous and narcissistic nature of male sexual desire but also an elaborate exposition of the rhetorical art with which men's pernicious desires can be redirected for the benefit of the city. By means of the gentle pronunciation of well-chosen words, the well-taught statesman can persuade his male citizens to marry unattractive women, father mediocre children, and care for their demanding broods-against their natural inclinations to the contrary.

As our city seeks to reckon with the current call for public approbation of male homosexual license, Plato's valedictory reflection on the constitution and care of the healthy body politic might help us begin to engage ourselves with the diagnosis and treatment of that which he-an ancient paragon of insight now invoked by both plaintiff and defendant in Evans $v$. Romer-most importantly took to be a civic malady, not a personal one.

154. HOMER, ODYSSEY I.110 (Richmond Lattimore trans., Harper Perennial 1991).

155. PlATO, supra note 3 , at $773 \mathrm{c}-\mathrm{d}$. 